$$
\text { نشريه تحليل فضايى مخاطرات محيطى، سال دوم، شماره س، ياييز عqس| صفحات عا-1-1 }
$$

\title{
تحليل فضايیى
}

بهلول عليجانى'، استاد آب و هواشناسى و مدير قطب علمى تحليل فضايى مخاطرات محيطى، دانشَاه خوارزمى.

$$
\text { دريافت مقاله: }
$$

جكيده

هدف اين مقاله تعريف تحليل فضايى و شرح مختصر مراحل تكوين آن در جغرافياست. براى اين منظور، از سالهاى قبل از

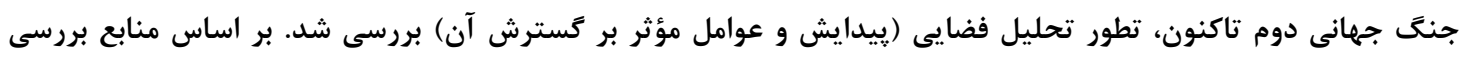

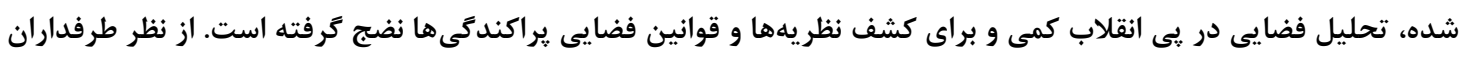

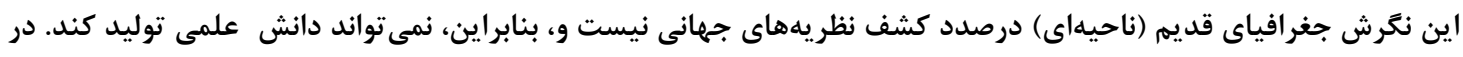

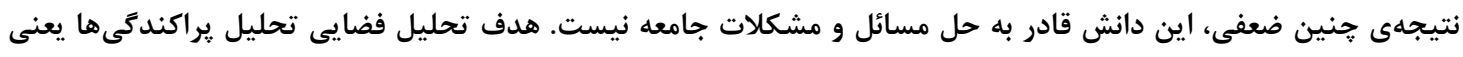

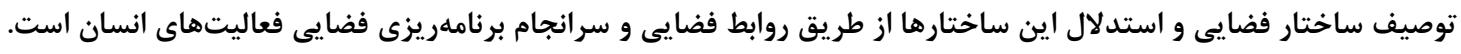

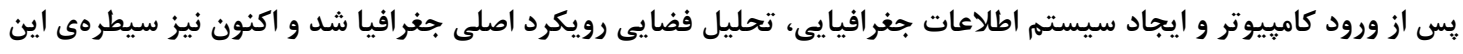

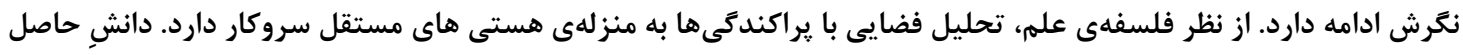

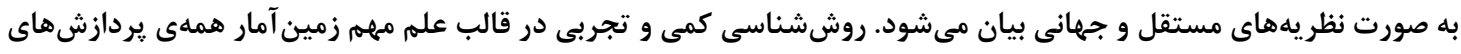

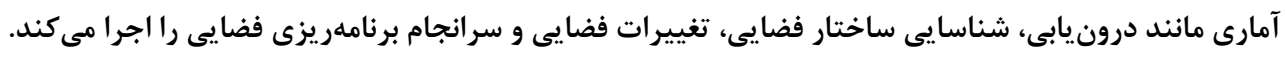

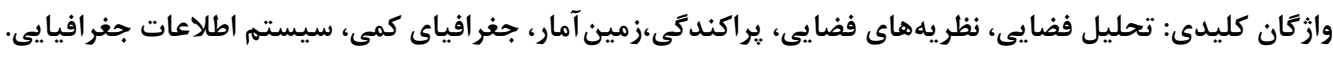


pattison, تحليل فضايى، به صورت ديدكاه اصلى، از ديخر نكرشهاى جغرافيا مانند نكرش انسان و محيط يا نخرش ناحيهاى

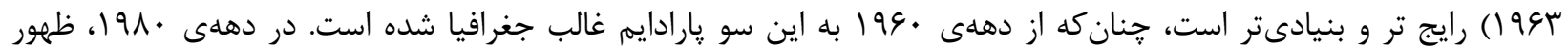
سيستم اطلاعات جغرافيايى بر تقويت اين نكرش و استمرار آن كمك شايانى كرد. جايخاه عملى نكرش تحليل فضايى محيط نرمافزار سيستم اطلاعات جغرافيايى است. به عبارت ديكر، اتر قبل از جنگ جهانى دوم آزمايشگاه جغرافيا را روى زمين

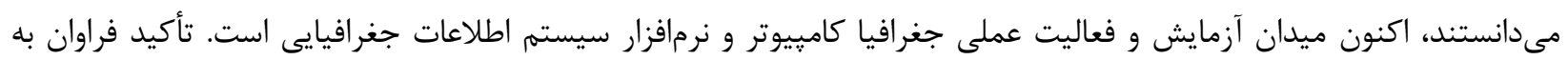
مسئلهى فضا و يراكندكى متغيرها بر روى آن سبب برترى يافتن و رجحان دادن نكَرشي تحليل فضايى از ساير نكَرشها شده است:

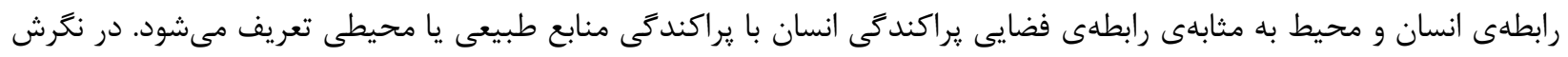

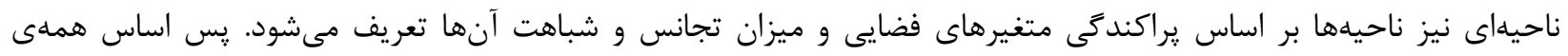
نكرشهاى ديكر هم يراكندكى ها و خگكونكى عملكرد آنها بر روى زمين است. تحليل فضايى بعد از انقلاب كمى رايج شد و عمدتاً

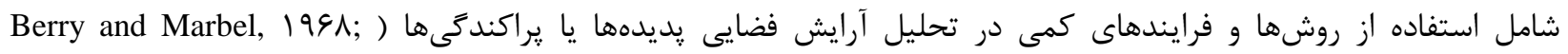

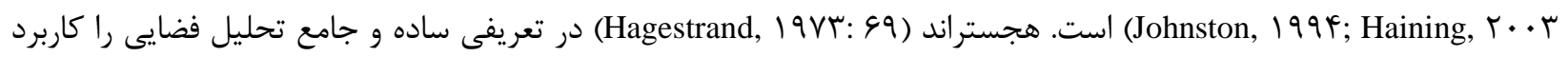
روشهاى كمى در مطالعهى دقيق و عميق الكوهاى نقطهاى، خطى و مساحتى بر روى نقشه بيان كرد. بعدها روشهاى مدلسازى و رياضيات هم به يردازش دادهاى جغرافيايى اضافه شد (Wilson and Bennet, 1919). تحليل فضايى دادهها مى كوشد دانش

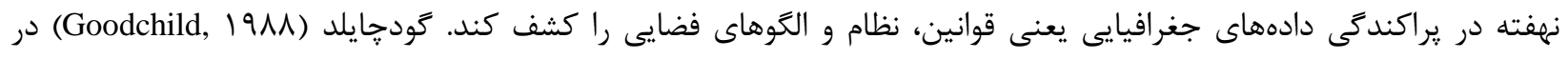

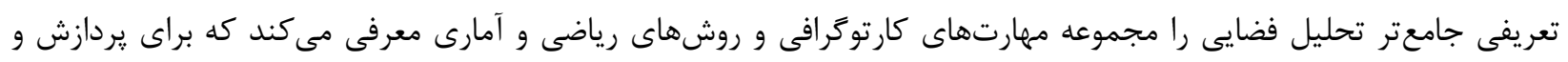
تحليل دادهاى فضايى به كار مىروند. به عبارتى سادهتر تحليل فضايى با استفاده از مهارتها و روش هاى كوناكون كمى مى كوشد

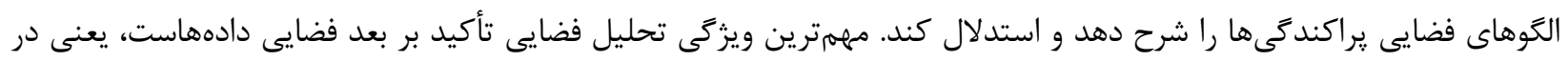

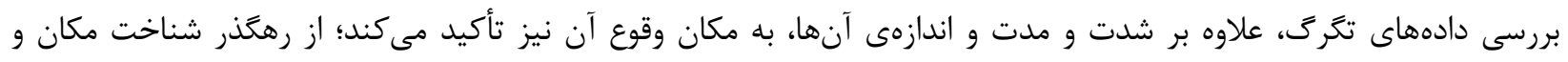

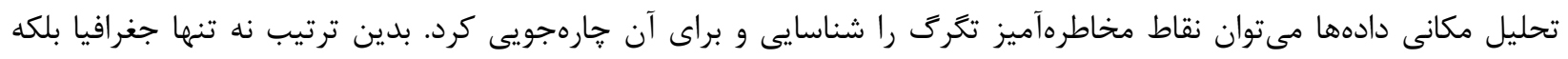
بسيارى از رشتهاى ديكر با روشىهاى تحليل فضايى مرتبط هستند، بيشترِ دادهاى خنين رشتههايى فضايى است و با سه مؤلفهى طول و عرض و ارتفاع شناسايى مى شود.

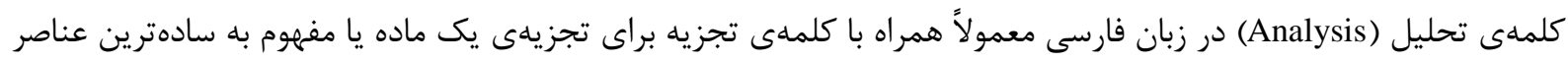

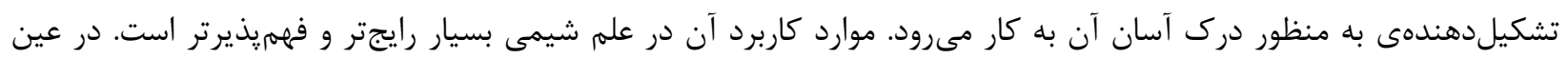

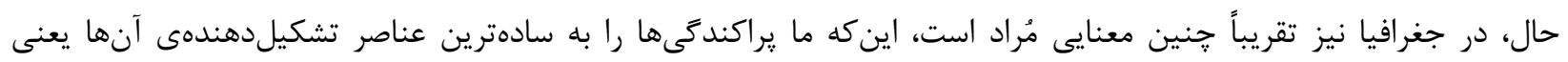

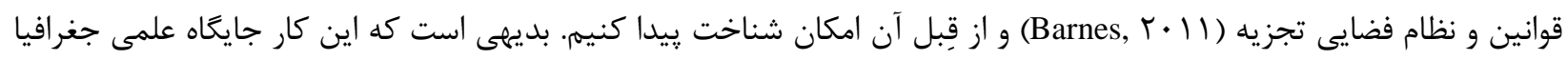
را محكمتر مى كند، زيرا نشان مى دهد كه علم كليات نيست و در هر موضوعى مى كوشد عناصر اوليهى را كشف و بر اساس آن

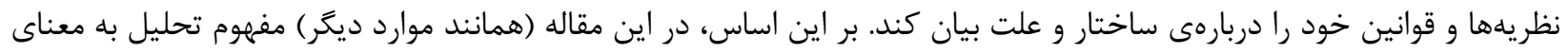
فرايند توصيف و استدلال يراكندگىها به كار مىرود. در واقع، مُراد از مفهوم تحليل فضايى نخست توصيف يراكندكى ها از نظر

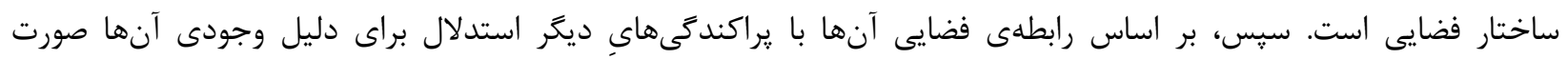

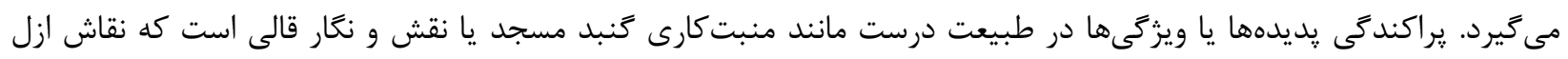


آن را به تصوير در آورده است. علاقهمند به هنر فرش اخر كمى دقت كند درمىيابد كه جنين آرايش به ظاهر يِيجيدهاى از تكرار يك گل يا خط منحنىاى تشكيل شده است. در زراكندكىها نيز جنين قراردادى حاكم است. از نظر طرفداران تحليل فضايى

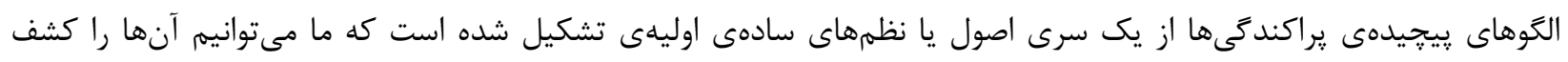

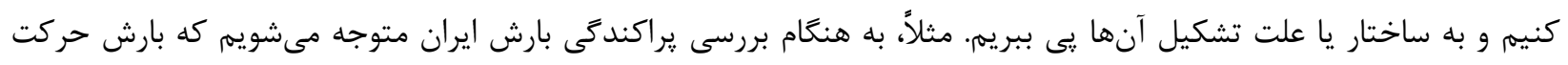

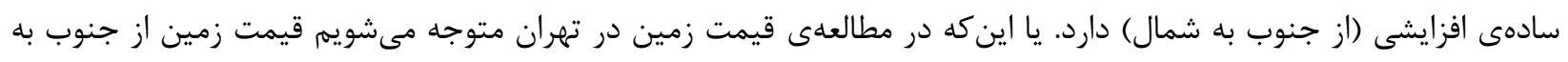

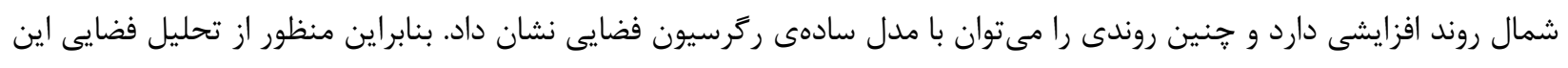
است كه ما يراكندكى ها را به عناصر حركتى فضايى تجزيه كنيم و ساختار آن را به صورت كمى و با زبان هندسى يا رئس رياضى شرح

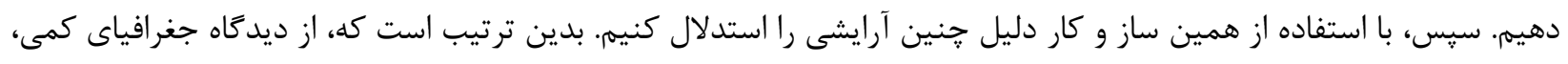
زبان جغرافيا رياضى و هندسه است (Bunge, 1999). بانكه با نوشتن كتاب جغرافياى نظرى (Bunge, 199r, 1999) بنيانهاى فلسفى رويكرد كمى و فضايى را محكم و مستند كرد. از نظر او اصلىترين ديدكاه جغرافيا ديد

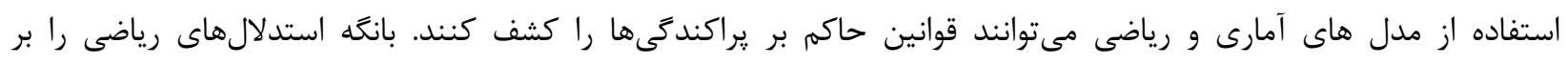

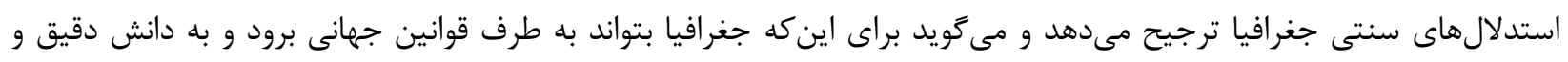

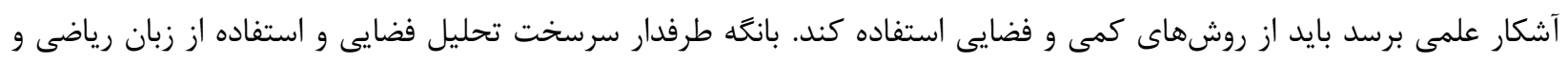
هندسه است و مى كويد جغرافى دانان بايد به جاى زبان نقشه از زبان رياضى يعنى مدلهاى فضى فضايى استفاده كنند، آرزويى كه امروزه

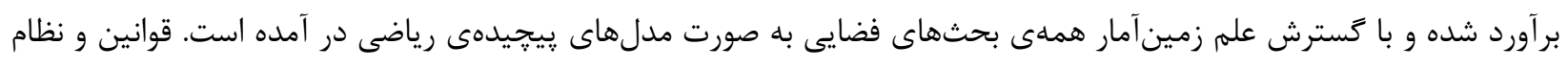

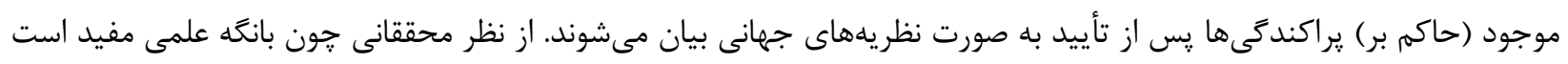

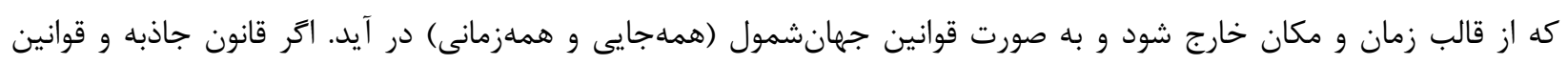

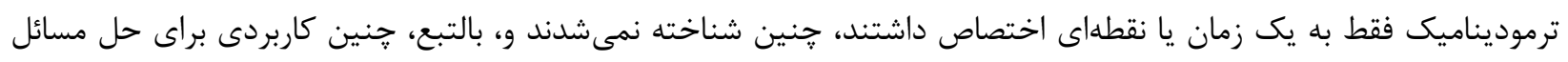
نداشتند.

تحليل فضايى در يى ناكارآمدى ديد

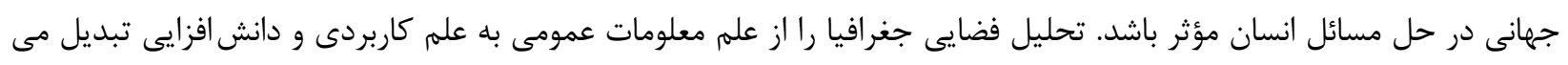

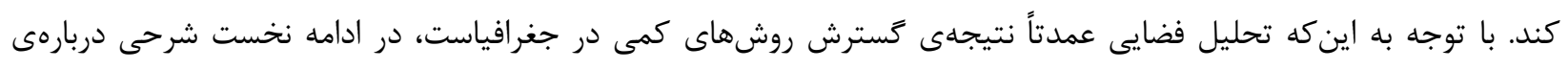

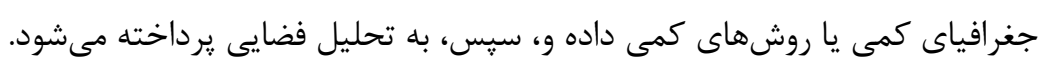

\section{جغرافياى كمى}

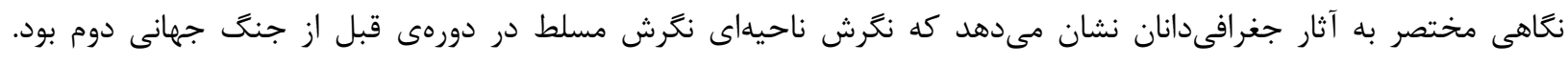

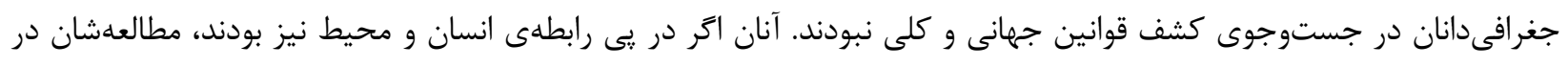
قالب ناحيهاى مشخص مى گنجيد. بديهى است، در هنين شرايطى رابطهى انسان با محيط نيز از ناحيهاى به ناحيهى ديخر متفاوت

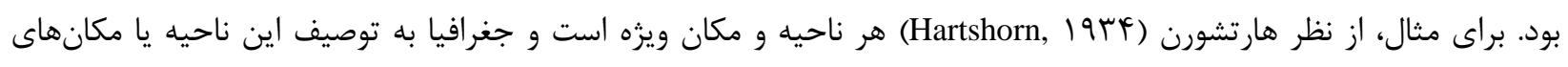

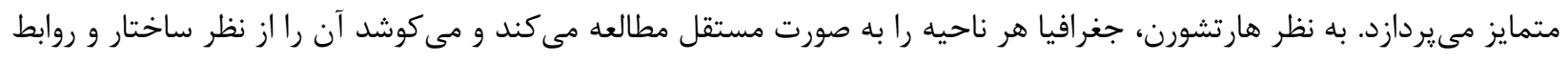
بين يديدهها به دقت بشناسد. در اين حالت، يزوهنده اگر به هر نظم و قانونى هم برسد، در مقياس محلى و ناحيهاى است و 
نمىتواند به همهى جاى دنيا تعميم دهد. از نظر او جغرافيا در يى روشهاى تحليلى (Analytic) و كشف قانون نيست. جغرافىدان

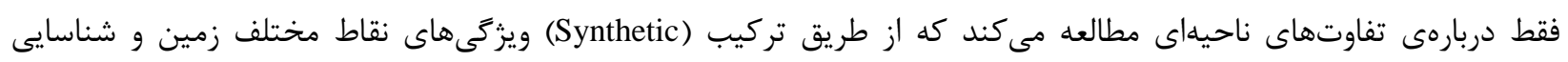
ناحيههاى متفاوت، وجه تمايزشان، حاصل مىشود. هارتشورن فضا (space) را به مكان (place) تقليل مى دهد و مشخصات مكانها (نقطهها) را مطالعه مى كند و آنها را بر اساس وجوه مشتركشان گروهبندى و ناحيه را تعريف و تحديد مى كند. اما در يى كسترش شاخههاى ديكر علم در زمينهى يديد آمدن و گَسترش نظريههاى علمى و گرايش جغرافىدانان براى ييوستن به كاروان علمى

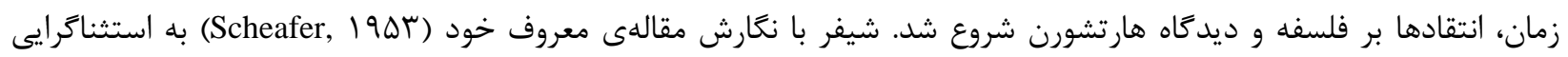
جغرافيا و ديدًاه هارتشورن انتقاد كرد. از نظر شيفر جغرافيا نيز همانند ساير علوم بايد در جستوجوى كشف قوانين و نظريههاى جهانى باشد. به نظر او، اكرجه ويزگكىهاى نقاط، مانند شاخص دما، با هم فرق دارد، اتر تغييرات دما را در يك فضا در نظر بخيريم متوجه مىشويم كه شباهتهايى در بين نقاط مختلف وجود دارد كه نظم يا قانون :براكندكى فضايى را مشخص يا كنترل مى كند.

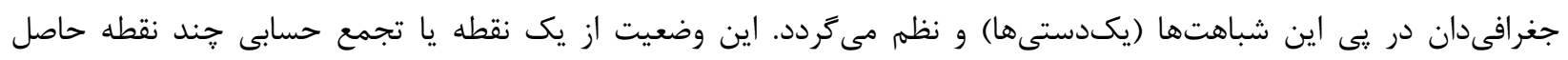
نمىشود، بلكه يراكندگى نقاط را بايد به صورت الكوى فضايى منسجم و بيوسته ديد تا به اين نظم و قانون رسيد. اين الكوى منسجم و يیوسته همان فضا را شكل مىدهد. بر اين اساس نبايد تصور كرد كه فضا فقط محصول انسان در طبيعت است؛ فضا هم

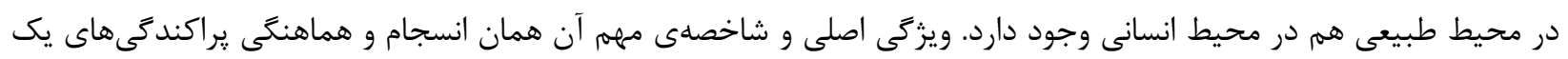

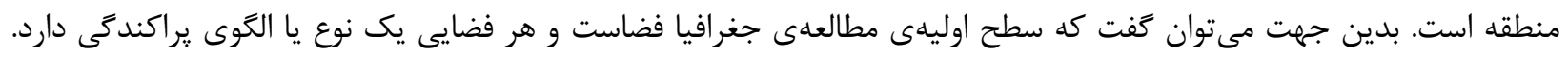

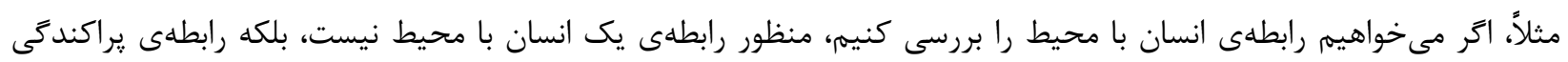

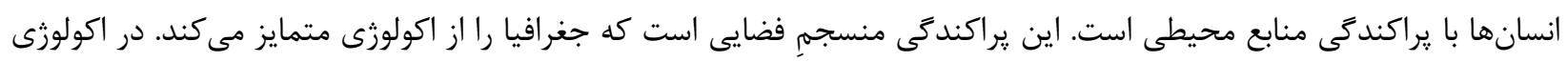

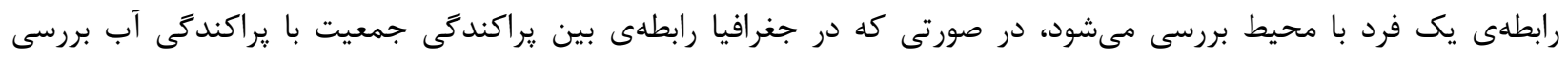

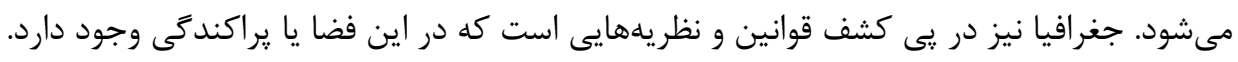
نيروى محركهى اوليهى جغرافيا براى انقلاب كمى ـ فضايى كشف قوانين و نظريه بود ــ كشف قوانين غير فضايى هر كدام از يديدهها در حيطهى علوم تخصصى مانند فيزيك و شيمى و زيستشناسى و غيره است؛ قوانين حركت را فيزيك، قوانين و فعل و انفعالات شيميايى را شيمى و قوانين رشد و تكامل حيات را زيستشناسى مطالعه مى كند. از نظر بانكه نيز، جغر افياى ناحيهاى بايد به حاشيه برود و تحليل فضايى توسعه يابد و اين تحليل قوانين و نظريههاى جهاني جغرافيا را كشف و عرضه كند. در ادامهى تفكر

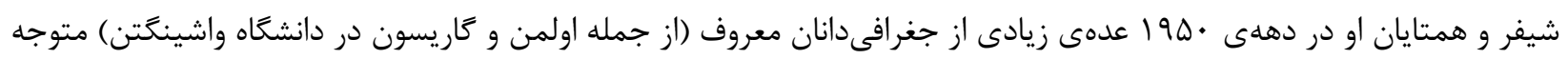
شدند كه جغرافياى قديم نمىتواند مسائل و مشكلات موجود را ياسخكَ باشد. آنان به اين نتيجه رسيدند كه نكَرش موجود بايد عوض شود و ديدًاه جغرافيا بايد همانند ساير علوم طبيعى (مانند فيزيك) باشد. آنان مطرح كردند كه براى فهميدن ماهيت

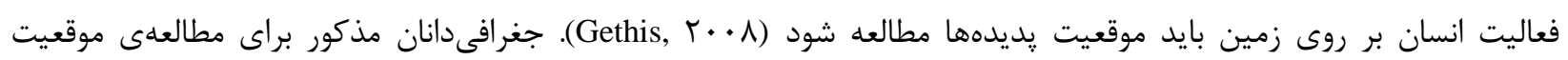

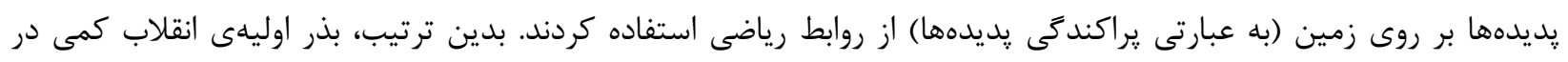
جغرافيا ياشيده شد و راه براى ديدگاه تحليل فضايى هموار كرديد. انقلاب كمى سه ويزَى مههم دارد: ا- توصيف بايد كمى و قابل تكرار و دقيق باشد. اولين كتاب دربارهى تحليلهاى كمى و

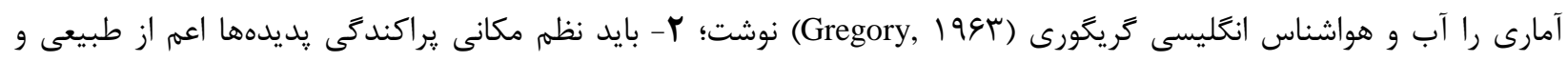
انسانى شناسايى شود. در دانشگاه واشنگتن، ادوارد اولمن و همكارانش مطالعاتى دربارهى نظم مكانى فعاليتهاى شهرى انجام 
دادند. در انگَلستان (دانشگاه كمبريج) هم جورلى با ادامهى روش فرضيهاى قياسى با تحليلهاى فضايى پديدهها را مطالعه كرد. پييتر هكت (Haggett, 1990) كتاب تحليل مكانى در جغرافياى انسانى را نوشت. نظريهى مكان مركزى وان تونن و نظريهى انتشار هجستراند هم كمك فراوانى به مطالعهى نظم مكانى كرد؛ r- روش تحقيق جغرافيا روش علمى يعنى روش فرضيداى قياسى كرديد. اولين كتاب در اين زمينه تببين در جغرافياى هاروى (Harvey, 1949) بود. اين كتاب استدلال رياضى و تحليل آمارى را

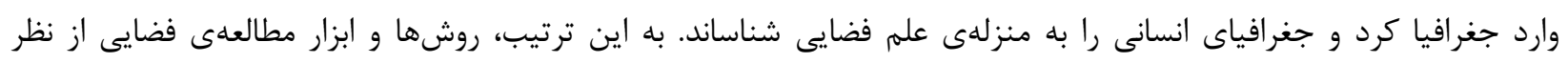

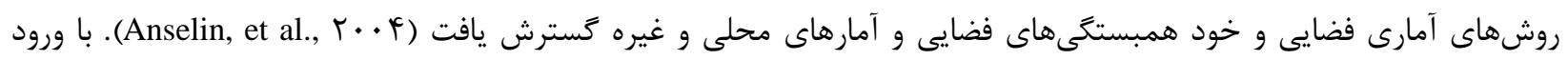
كامييوتر تكنيك بسيار ييجيدهى سيستم اطلاعات جغرافيايى رونق يافت كه بعدها مههمرين ابزار توسعهى تحليل فضايى گرديد. از

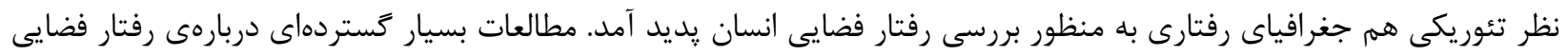
انجام شد. تحليل الكوها و تحليل فاصله و اقتصاد فضايى (Spatial Economy) همه در دورهى شكوفايي جغرافياى كمى و تحليل فضايى صورت گرفت. هدف انقلاب كمى تبديل توصيف كلامى يراكندگى ها به توصيف كمى بود. آنان به جاى استفاده از عبارت "جنكلهاى شمال

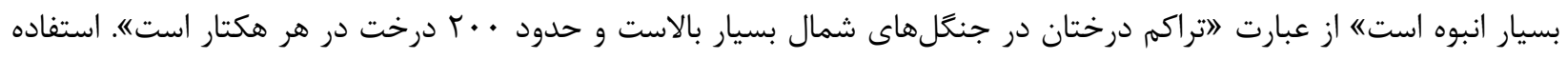
مى كنند. توصيف كمى به محقق و كاربر اطلاعات دقيق مىدهد كه اكر خواست بتواند ميزان بهرهبردارى خود را تعيين و استفاده كند. روشهاى كمى و آمارى انقلاب كمى ابتدا ساده بود و اكثر جغرافىدانان از روشهاى معمولى مانند ركرسيون استفاده مى كردند. اما بعد روشهاى كاملتر و يِيجيدهاى مانند تحليل عاملى و تحليل الكوهاى نقطهاى از تخصص هاى ديگر گَرفته شده و

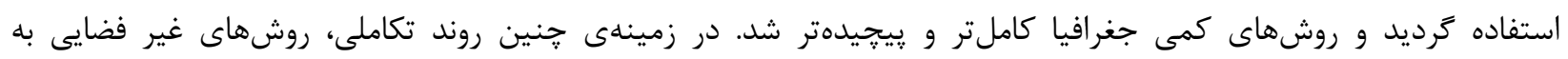

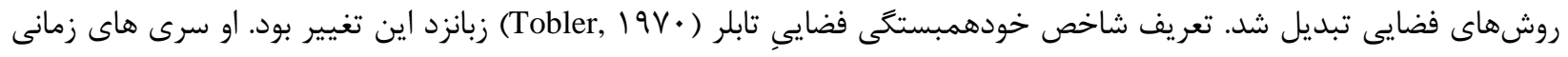
را در تغييرات مكانى به كار برد و سرىهاى فضايى را تعريف كرد. همجنين او ميانگين متحرك و واريانس فضايى را ابداع كرد.

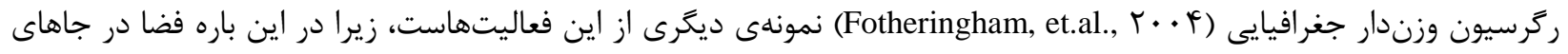

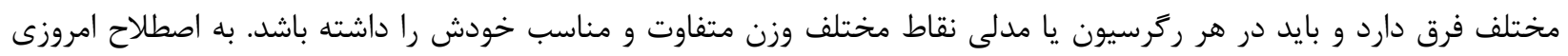

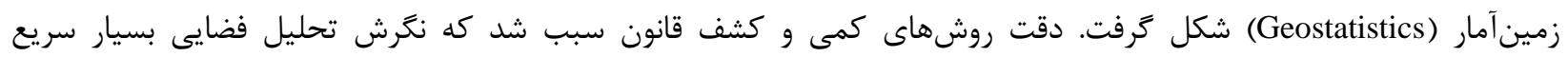
كسترش يابد. روشهاى كمى به دلايل زيادى (·Fotheringham, et.al., r... رواج يافت:

ا - دادههاى جغرافيايى روز به روز زيادتر و زيادتر مىشد، به طورى كه يردازش و خلاصهسازى آنها با مغز انسانى عملاً ناممكن مىشد؛ r- نهضت استفادهى كاربردى و دقيق از يافتههاى جغرافيايى سبب شد كه از روشهاى آمارى دقيقى براى اين محاسبات

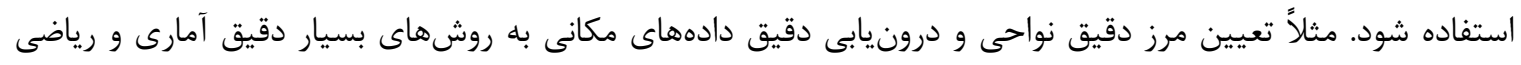
نياز داشت؛ ז- شرط اول استفاده از كاميوتر در يردازشهاى جغرافيايى تهيهى دادههاى دقيق و قابل استفاده در كامييوتر بود؛ F- مهمتر از همه، مشاهدهاى ميدانى جغرافيايى قديم به مطالعهى عكسهاى هوايى و تصاوير ماهوارهاى تبديل شد كه استخراج داده از اين تصاوير به روشهاى آمارى دقيق و بيجيدهاى نياز داشت؛ 
ه- بالاتر از همه، زبان علم رياضى است و جغرافىدانان براى عرضهى يافتهها و نظريههاى خود به متخصصين ديگر بايد آنها

$$
\text { را به صورت مدلهاى رياضى تعريف مى كردند. }
$$

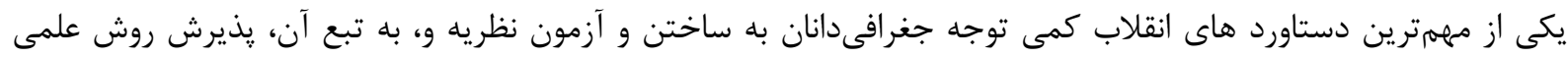
است. بر اين اساس، آنان در فرايند استقرا و در طول يزوهش اكتشافى نظهم مكانى يراكندگى ها را مشاهده مى كنند و بر اساس آن

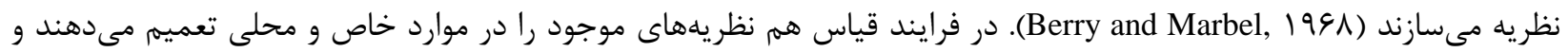

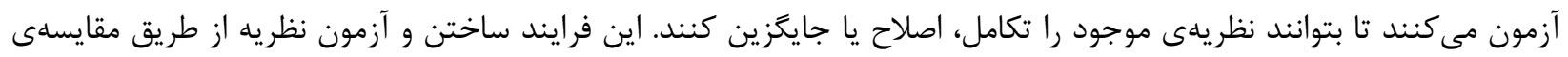
آن با حقيقت سنگ يايهى اصلى روش علمى است. روشهاى كمى ابزار مناسبى براى تنظيم و آزمون نظريهها فراهم كردند. در واقع جغرافيا را رياضياتى و قانونمند كردند. آنان يذيرفتند كه تنها راه رسيدن به دانش علمى معتبر همانا ساختن و آزمون نظريه است. علاوه بر مدلهاى قياسى، مانند نقشه، مدلهاى رياضى هم براى نمايش عينى نظريهها استفاده شد. فرايند مدلسازى بر

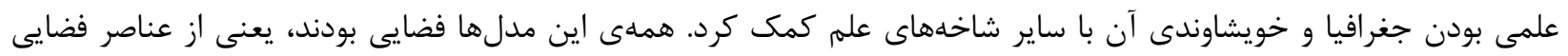
(نقطه، فاصله، جهت) تشكيل شدهاند. بدين ترتيب توسعهى انقلاب كمى سبب توسعهى تحليل فضايى گرديد. در نتيجه، در يى انقلاب كمى و با اتكا به فلسفهى اثبات گرايى، تحليل فضايى به مثابهى مسير اصلى جغرافيا در آمد. نخرش تحليل فضايى ابتدا در جغرافياى انسانى رايج شد و سيس به جغرافياى طبيعى هم راه يِيدا كرد. شاخهى آب و هواشناسى و جغرافياى زيستى كاملاً

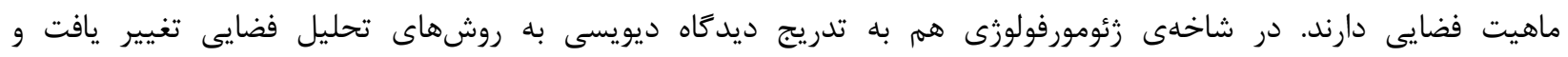
اندازمخيرىهاى كمى در حوضههاى آبريز (مانند فيزيوگرافى حوضه و حركات دامنهاى) شروع شد. در اين باره، بانكَ اظهار كرد بعد از روى آوردن به تحليل فضايى متوجه شديم جرا رودخانهها ماندر دارند. براين برى در زمينه موضوعات شهرى كار كرد. در

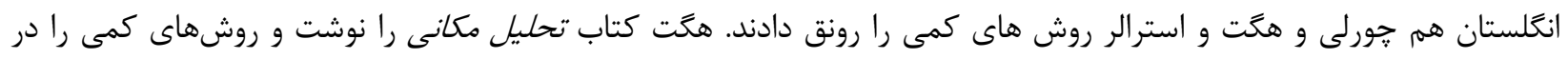

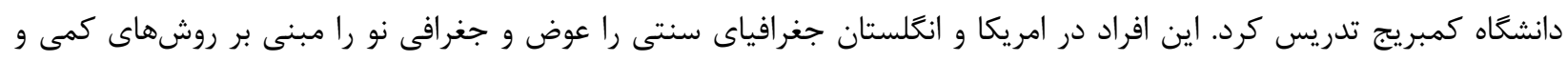

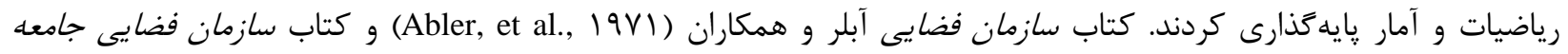

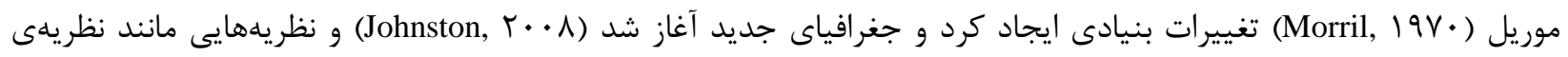

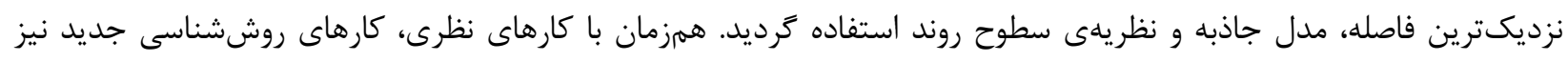
مطرح شد. در دهلى •99 1، كه اوج رشد روشهاى كمى و تحليل فضايى بود، كتابهاى مهمى در اين زمينه نوشته شد، مانند

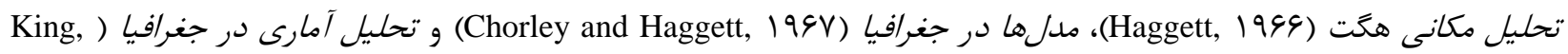

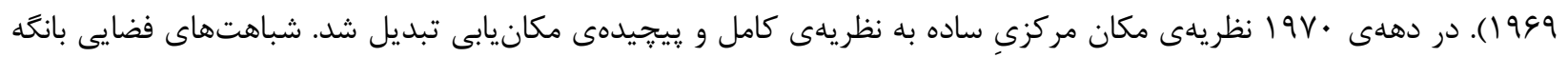

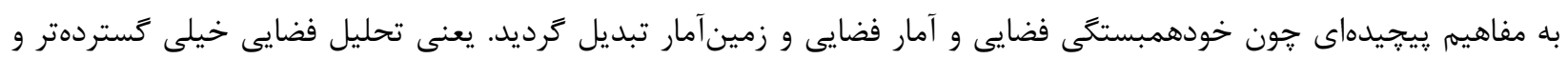
קוيجيدهتر شد.

\section{تحليل فضايیى}

منشأ تحليل فضايى يِيشينهاى طولانى دارد و به زمان بطلميوس (Ptolemy) (191 تا • و پِيش از ميلاد)، جغرافى دان مصرى، بر مى گردد كه مى گفت براى درك يديدههاى زمين بايد آنها را تجزيه كرد. زيرا از طريق تجزيه الكَوها به روابط و عناصر ساده و و اوليه

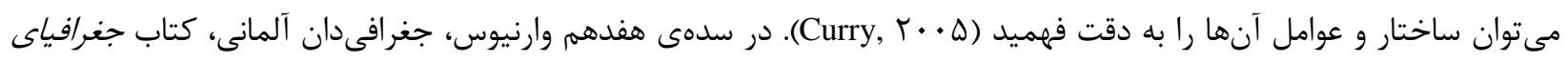


عمومى را بر اساس آراى بطلميوس نوشت. در اواخر قرن هفدهم و اوايل قرن هجدهم، نيوتون كتاب وارنيوس را در كمبريج تدريس كرد. در اواسط قرن نوزدهم تحليل فضايى در فرم كارتوكرافى و زئودزى و جغرافياى رياضى به صورت دروس اصلى تدريس جغرافياى دانشكاهى در آمد. ورود كامييوتر به جهان علم سبب تحول و بسط هر خه بيشتر تحليل فضايى شد. تحليل فضايى به مرتبهاى فراتر از يارادايم رسيد، يعنى به جاى افول احتمالى در آينده ويزگى ذاتى جغرافيا شد و با اتكا به سه ركن اصلى يعنى فلسفهى اثبات گرايى، انقلاب كمى و يردازشهاى كامييوترى به صورت مسير و جهارجوب اصلى تحقيقات جغرافيايى در آمد. اين

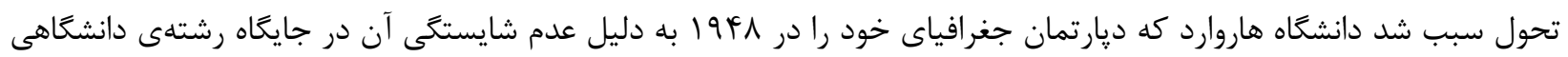

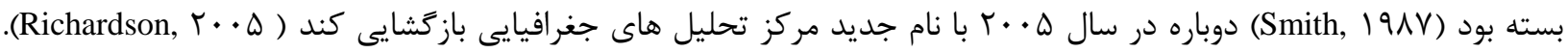
بهترين و واضحترين آغاز تحليل فضايى نخارش كتاب معروف برى و ماربل در زمينهى تحليل فضايى (Berry and Marble, 1991)

جغرافياى طبيعى تا اواسط دهلى • له 19 به صورت توصيف كلامى دربارهى ديدكاه ديويس بود و خيلى تغيير نداشت. اما جورلى در دانشكاه كمبريج تحليل فضايى را در زئومورفولوزى تبيين نمود. تابلر هم كارتوگرافى را تغيير داد و تحليل فضايى را در آن مطرح كرد. او با تركيب كارتوكرافى و رياضياتْ جغرافياى تحليلى را يايهگذارى كرد. ديويد هاروى با نوشتن كتاب تبيين در جغرافيا تحليل فضايى را از نظر فلسفى محكم كرد. بك (Beck, 199V)، كه جغرافىدان نبود، پِ از بر بررسى تحقيقات دهdهاى

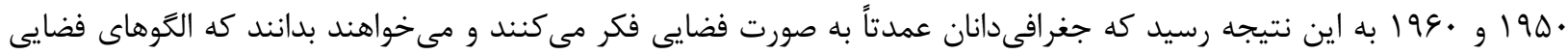

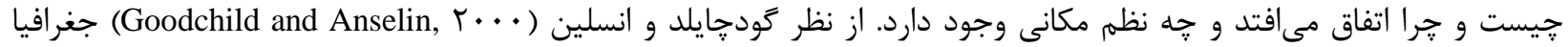
مى كوشد رابطهى بين انسان و محيط را در روى مكان به تصوير در آورد و، در اين باره، مى كوشد نظريهى فضايى را بسط دهد. او

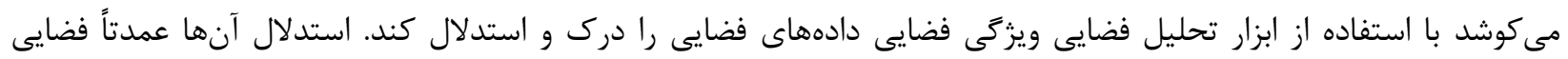
است. موجزتر اينكه جغرافىدانان فضايى فكر مى كنند و هر بحث يا موضوعى را در قالب اصول و معيار هاى فضايى بررسى مى كنند. مفاهيم اوليهى جغرافيا عمدتاً منشأ فضايى دارد. از مفاهيم اوليه مىتوان به موارد زير اشاره كرد: هويت مكانى، مكان، مرز، فاصله. مفاهيم كلان از تركيب اين مفاهيم ساخته مىشوند، مانند يراكندگى از تركيب جندين مكان، ناحيه از تركيب جندين يديدهى مكانى و جهت و جهت گيرى، سلسلهمراتب و حاكميت مكانى از تركيب بزركى و مكان. همجنين، در بيى اينها مفاهيم

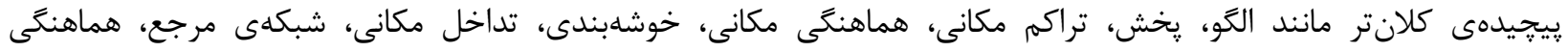

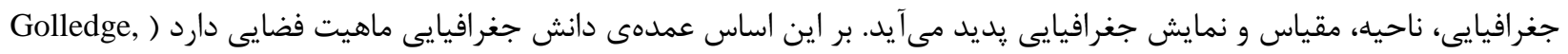

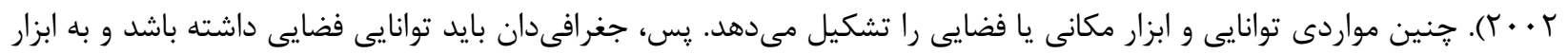
فضايى مسلط باشد تا بتواند به دانش جغرافيايى دسترسى پيدا كند. همهى اين بحثها در نخرش تحليل فضايى شكل ترفتهاند. كولج، در تحليلِ نهايى، نتيجه مى ابزار فضايى مسلط شود. در جهارجوب تحليل فضايى نظريههاى مههم جغرافيايى مانند وابستكى فضايى، ناهمگنى فضايى، تداخل

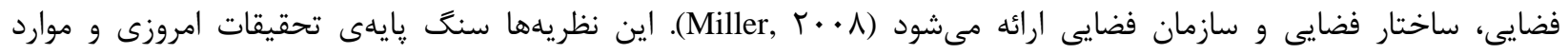
كاربردى علم جغرافيا را تشكيل مىدهد. وابستگى يا خودهمبستگى فضايى در كنار ساختار منطقهاى محور اصلى درونيابى جغرافيايى و علم زمينآمار است. ناهمخنى فضايى تحقيقات ناحيهبندى را پايهَذارى كرده است. نظريهى تداخل فضايى اساس 
همهى حركتهاى فضايى مانند مهاجرت و انتشار فرهنَّها را تشكيل مىدهد. سازمان فضايى منطق فضايى را ايجاد مى كند و فرايندهاى فضايى بر اساس سازمان فضايى انجام مىشود.

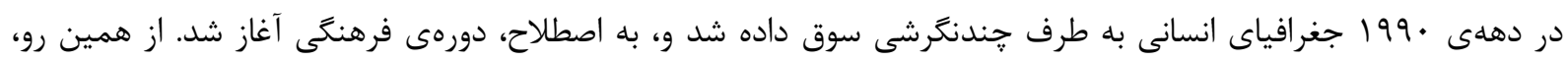
تحليل فضايى تا حدودى محدود و ضعيف شد. اما مجدد در قرن بيست و يكم جغرافياى انسانى غير مستقيم دو روش كمى و كيفى را در تحقيقات خود يِش گرفت. تحقيقات كمى به طرف تحليل فضايى و روشهاى كمى رفت و تغيير دورهى فرهنكى و ورود

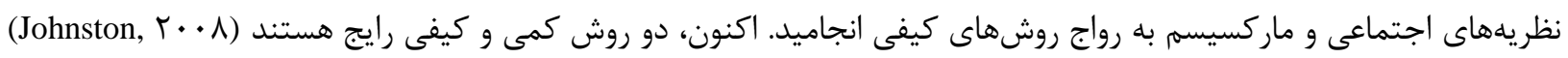

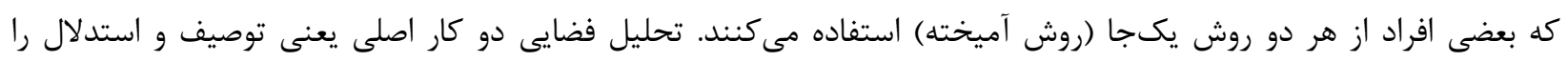
دربارهى الكوهاى يراكندگى مكان انجام مىدهد. حتى بيشبينى نيز مى كند و آثار تغييرات رفتار فضايى انسان را در جشهماندازهاى

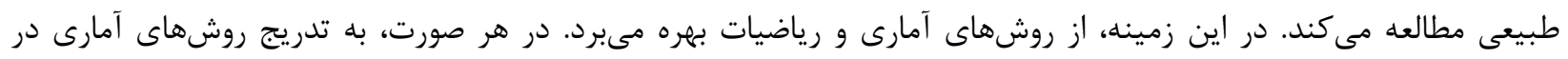
جغرافياى انسانى گسترش يافت و تحليل فضايى به صورت نكرش عميق و يايهاى در مطالعات جغرافيا در آمد. امروزه، به استثناى بعضى موارد مطالعات كيفى، در اكثر مطالعات كل جغرافيا روشهاى كمى و رياضى رايج شده است. هيج جغرافىدانى نمىتواند

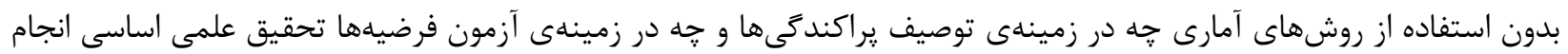

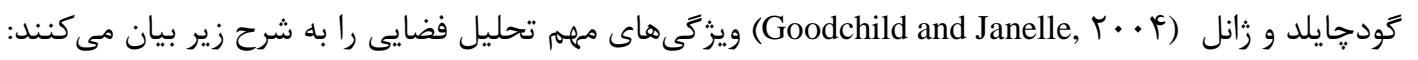

ا - در رويكرد فضايى دادهها از همهى منابع با همديكر يكيارجه مىشوند، زيرا فضا تنها ظرفى است كه مىتوان همهى دادهها را در آن قرار داد؛ r- الكوهاى فضايى ما را به عوامل و فرايندهاى كنترل كنندهى آنها هدايت مى كند؛ r- نظريdهاى فضايى بر اساس عناصر اوليهاى مانند فاصله، مكان و جهت ساخته مىشوند، براى نمونه ركرسيون وزندار

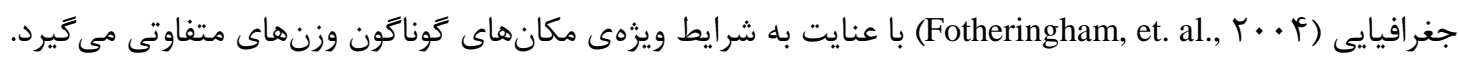

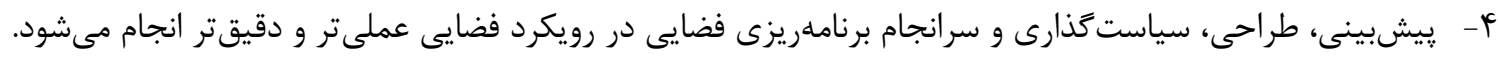

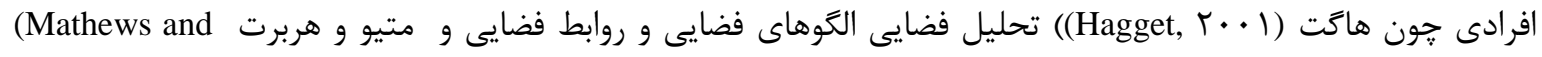

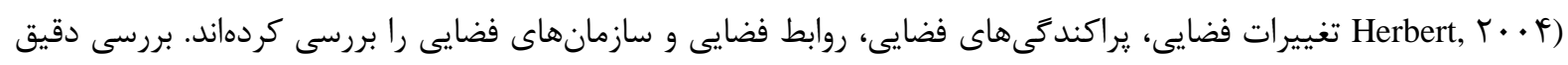
קهار يرسش جغرافيا (نخستين برسشها) نيز تحليل فضايى را تداعى و تفسير مى كند. دو سؤال جه جيز و كجا موضوع

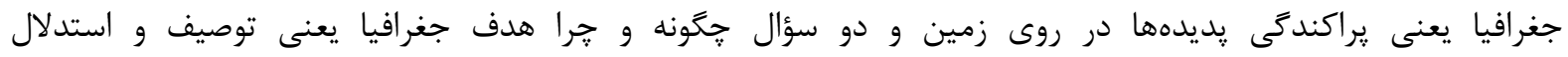
يراكندكىهاست. بعضىها نيز تحليل فضايى را علوم فضايى مىنامند و بر آن هستند كه اين تحليل دربارهى الكوها و

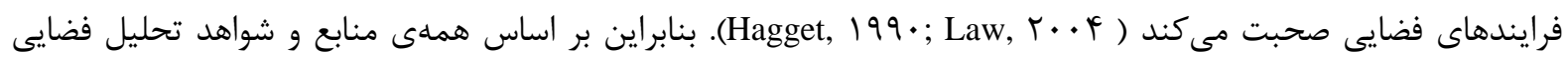
ديدگاه اصلى و كاربردى جغرافيا است. 


\section{تحليل فضايى از ديدكاه فلسفه علم}

با توجه به مطالب بِيشين، فرايند تحليل فضايى توصيف جگَونكى و استدلال جرايى يراكندگىها را شامل مىشود. نتيجهى اين

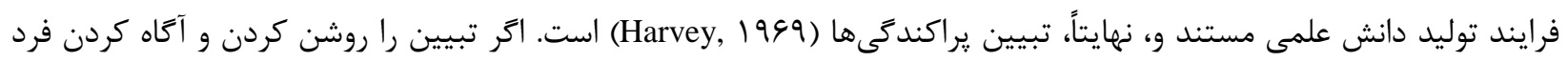
دربارهى يديده يا فرايند تعريف كنيم، نتيجهى هر دو فرايندِ توصيف و استدلال تبيين است. در فرايند توصيف نظريهها ساخته مىشوند و در فرايند استدلال نظريههاى موجود براى ياسخگ

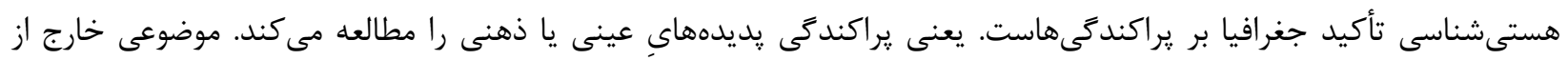
محدودهى يراكندگى نمى تواند موضوع جغرافيايى باشد. البته بحثها و تحقيقاتى هم در زمينهى مسائل عمومى و سيستماتيك

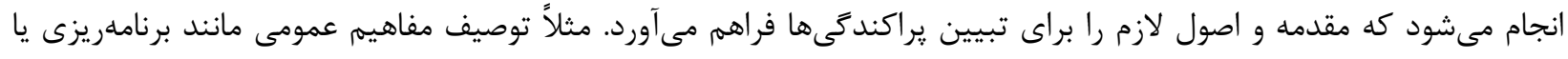
مهاجرت در جهارجوب موضوعات جغرافيايى مطالعه مىشود. تعريف و تحديد مفاهيم جغرافياى طبيعى (تيهى ماسهاى، بارش، درخت و غيره) مفاهيم مستقل و واقعى هستند و با تفكر انسان تغيير نمى كنند. اما مفاهيمى جون خطر، بحران، بارش شديد و مديريت خوب مفاهيم ساختهى ذهن انسان است و از فردى به فرد ديكر فرق مى كند. با وجود اين مطالعهى آنها براى جغرافيا

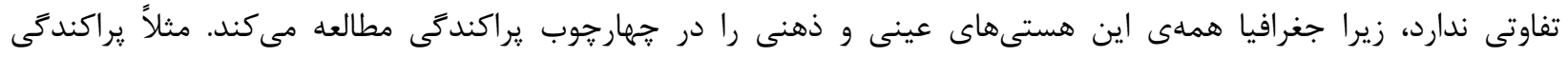

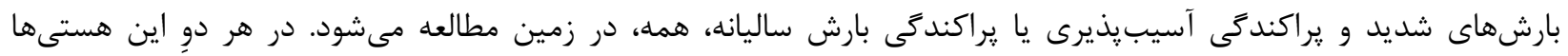
ويزگگ فضايى آنها هستى مستقل و عينى است، يعنى اينكه مكان بارش شديد و سيل خسارتبار وجود دارد و مستقل و عينى

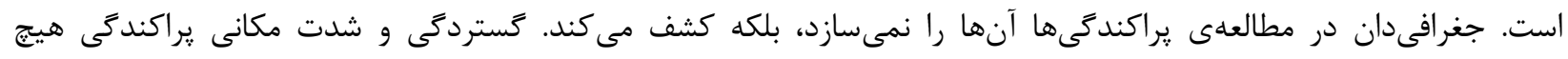
ارتباطى به تفكر جغرافىدان ندارد و جغرافىدان در تحقيق مشاركت ندارد، يعنى در نتايج تحقيق اثر ندارد و نتايج مستقل از آراى

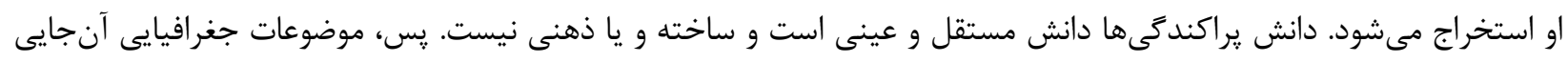
كه به زمين مربوط مى شوند مستقل هستند و فقط خود متغير مىتواند عينى يا ذهنى باشد. بر اين اساس موضوعات مورد مطالعهى تحليل فضايى از نظر مكان زمينى و عينى هستند.

روششناسى جغرافيا در حيطهى يراكندگىها روششناسى كمى و تجربى يا عينى كراست. يعنى محقق بايد يراكندگى يديدهاى طبيعى مانند تيههاى ماسهاى يا فراوانى شهرها و زمينهاى كشاورزى را مطالعه و به صورت نقشه ترسيم كند. اين نوع روششناسى كاملاً روششناسى كمى و تجربى است. مفاهيم جغرافياى طبيعى در كل با روش تجربى مطالعه مىشوند. در

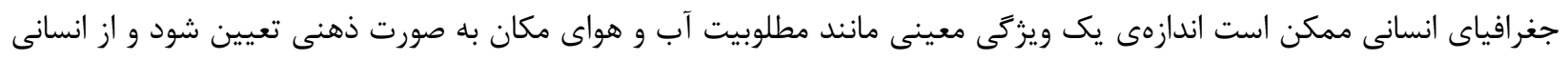
به انسان ديكر فرق داشته باشد. در اينجا نيز نقشهى يراكندگى از طريق تجربى و كمى حاصل مىشود. تفاوت اصلى در ساختن مفاهيم انسانى است كه به صورت ذهنى ساخته مىشود. اما ترسيم نقشه و تحليل متن نقشه از طريق تجربى انجام مىشود. از نظر معرفتشناسى دانش نهايي تحليل فضايى بايد نظريههاي مستند به دست دهد. يعنى از اين نظر تحليل فضايى در يارادايم

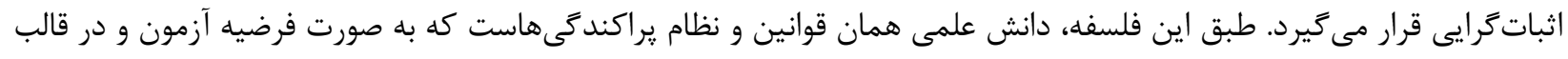
نظريه بيان مىشود. روش كسب اين دانش هم تا جايى كه به روشهاى تحليل فضايى مربوط مىشود تجربى و كمى است. امروز خيلى از جغرافى دانان حتى در جغرافياى انسانى هم براى رسيدن به دانش مستند و آزمون فرضيههاى خود از اثبات گرايى انتقادى استفاده مى كنند. از نظر اصول منطق هم بايد اين طور باشد، زيرا در هر دو شاخهى جغرافيا نظريه از طريق روش استقرا حاصل مىشود. در روش استقرا به يافتهاى محرز نمىرسيم. از اين روست كه فرضيه تأييد شده نظريه ناميده مىشود نه قانون. در ديد 
تحليل فضايى جغرافى انان بر اساس اين نظريهها توزيع جمعيت انسانى در زمين و بهرهبردارى از منابع را برنامهريزى و بيشبينى مى كنند.

دربارهى اثبات كرايى، كفتنى است تلقى منفى از آن را جامعلشناسان براى كسانى بيان كردند كه درصدد بودند مسائل جامعه را بر اساس قوانين طبيعى مديريت كنند. از نظر جامعهشناسان منتقد قوانين سخت طبيعت در جامعلى انسانى وجود ندارد. ترديد كمى مى توان دربارهى جنين كزارهاى كرد؛ صحت مسائل اجتماعى از قوانين محكمى مانند طبيعت تبعيت نمى كنند. اما

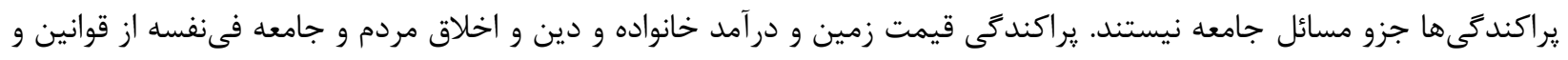
نظريههاى محكم تبعيت مى كند. از اين رو، جغرافىدانانى كه فلسفهى اثبات گرايى را ـ به هر شكلى كه باشد ـ ملامت مى كنند شايد از واقعيت و ماهيت مطالعهى جغرافيا آكاه نيستند. جغرافيا با مسائل جامعه سر و كار ندارد. جغرافيا در بیى تصميمگيرىهاى غير فضايى انسان و تغيير اخلاق و رفتار او نيست، بلكه جغرافيا يراكندكىهاى حاصل از رفتار انسان را مطالعه مى كند. از اين نظر،

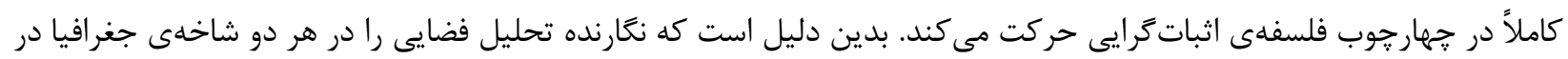
حيطهى فلسفهى اثبات كرايى مى داند كه بايد به نظريههاى فضايى ختم شود. زمينهها يا موضوعات مهمم مطالعهى تحليل فضايى به شرح زير خلاصه شدهاند: توصيف جـكونكى يراكندگى ها. اولين كار مطالعهى جغرافيايى يا تحليل فضايى شرح ساختار يراكندگى هاست. منظور از ساختار وجود هر نوع رفتار فضايى به غير از حالت تصادفى است. يراكندگى دادههاى جغرافيايى تصادفى نيست. هر نوع يراكندگى يك الكو ناميده مىشود و يكى رفتار فضايى خاصى دارد كه بر اثر دليل خاصى ايجاد شده است. مثلاً يراكندكى و كاهش تراكم درختان در در

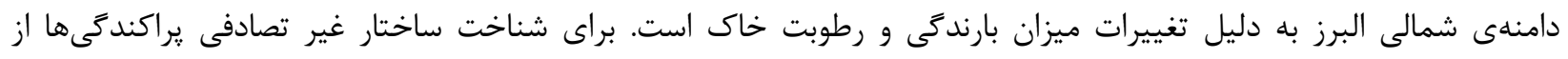
شاخصهاى آمارى متعددى استفاده مىشود. يس از شناسايى ساختار يراكندگى، ويزَى هاى كلى آن مانند ميانگين و واريانس فضايى بررسى مىشود. اولين قدم در شناخت ساختار يراكندگىها مطالعهى اكتشافى آنهاست كه با مشاهده و اندازهيرى آهاى كمى ساختار كلى به دست مى آيد. مثلاً، دربارهى فراوانى سرماهاى خسارتبار در ايران متوجه مى شويم كه در مناطق كوهستانى

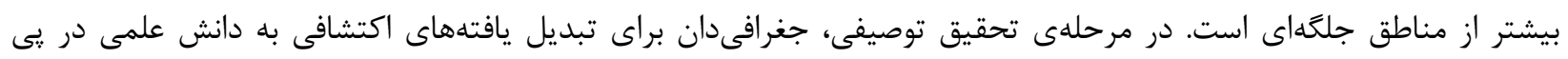

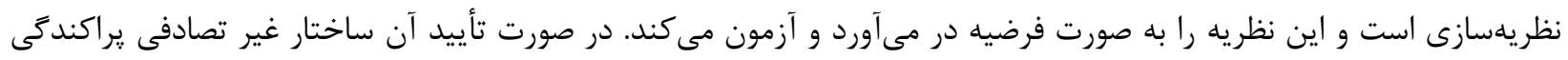
شناخته مىشود. ناهمكنى فضايى يراكندگى با استفاده از شاخص واريانس فضايى اندازمكيرى مىشود. از روى اين شاخص نواحى جغرافيايى شناسايى مى شود. ساختار فضايى يا رفتار غير تصادفى به دو صورت مشاهده مى شود. ساختار منطقه ایى تغيير منظم

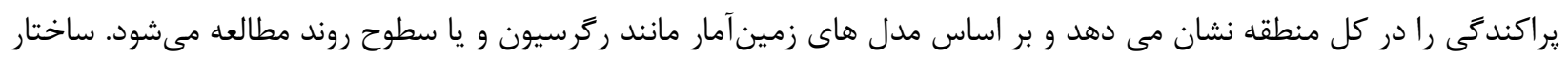
محلى(Tobler, laV)، در هر نقطه اى تا شعاع معينى مشاهده مى شود و با استفاده از شاخصهايى مانند واريوكرام شناسايى مىشود. ساختار فضايى همان نظم مكانى است كه جغرافيدان در مطالعه يراكندگى ها بدست مى آورد. اكر اين نظم مكانى در نقاط متعدد جهان مشاهده شود به صورت قانون فضايى مطرح مى شود. مثلا اكر دما در اكثر نقاط جهان با ارتفاع كاهش يابد به صورت

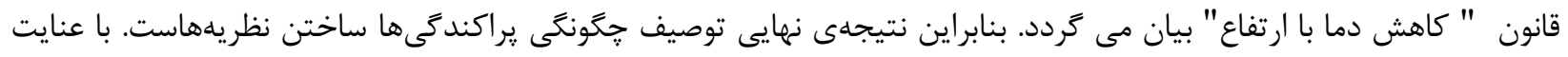
به اينكه روش اصلى مطالعه در توصيف يراكندگىها استقراست و يافته استقرايى هم صد در صد نيست، يافته حاصل نمى تواند قانون تلقى شود. در نتيجه تئورى يا قانون تجربى كفته مى شود. اين تئورى يا نظريه ممكن است بعداً اصلاح يا تغيير يابد. 
شناسايى تغييرات در امتداد مؤلفههاى مكان يعنى عرض و طول و ارتفاع نيز توصيف است و نه استدلال. شناسايى رابطهى فضايى بين دو براكندگى هم مانند رابطهى بين رطوبت خاك و تراكم يوشش كياهى براى اولينبار توصيف ناميده مىشود. در واقع نكرش

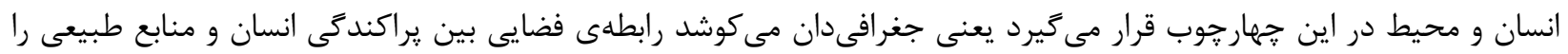
(ماند آب و خاك و يوشش كياهى) مطالعه كند. يس معلوم مىشود كه نكرش تحليل فضايى عميقتر و گستردهتر از ديكر نكرشهاست و همه آنها را در بر مى كيرد. دستاورد نهايى تحقيق توصيفى موارد زير است:

- شرح ويزگى هاى عمومى يراكندگى مانند ميانگين و واريانس و كوواريانس و ضريب تغييريذيرى و بيضى استاندارد؛

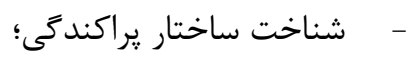

- - شناسايى روند تغييرات منطقهاى در راستاى مؤلفههاى مكان و هر امتداد ديخرى؛

- شناسايى ناحيههاى ممكن بر اساس يك يا جند متغير؛

- - شناسايى رابطهى فضايى بين دو يا جند متغير؛ رابطه انسان و محيط در اين دستاورد قرار دارد.

استدلال يراكندكىها. جغرافيا نيز مانند همهى علوم ديگر در يى علت و دلايل يراكندكىهاست. بدين جهت بعد از انقلاب كمى استدلال يا تحقيق استدلالى جزو مطالعات جغرافيا قرار ترفت كه بسيارى آن را جغرافياى علمى ناميدند. البته به كار بردن مفهوم علمى فقط به مطالعات استدلالى درست نيست، زيرا هر دو فرايند توصيف و استدلال تلاش علمى هستند و منجر به نظريه يا دانش علمى مىشوند. استدلال جغرافيايى استدلال فضايى است يعنى اينكه در توجيه براكندگىها از رابطهى فضايى بين آنها با يراكندگى (هاى) ديكر استفاده مى كند. براى استدلال فراوانى سيلاب در شهر تهران به يراكندگى هاى ديكرى مانند شدت بارش و شيب زمين و يوشش كياهى توجه مىشود. افزايش شدت بارندىى به مقادير بالاى ظرفيت نفوذيذيرى خاك، افزايش شيب زمين و كاهش تراكم يوشش كَياهى سبب فراوانى سيل مىشود. بدين جهت محقق جغرافيا بايد بر اساس معلومات خود و با استناد به

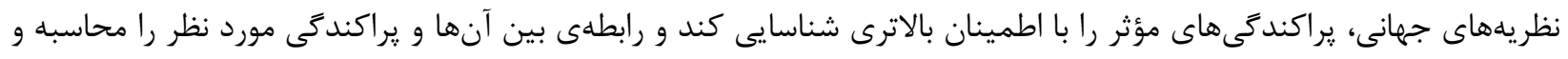
آزمون كند تا عوامل يا يراكندگى (هاى) مؤثر شناخته شود. يردازش و انجام جنين رابطهاى به اندازهگيرى و محاسبات رياضى و آمارى نياز دارد، يعنى فرايند تحليل فضايى. استدلالهاى روش كمى معمولاً با آستانهى اطمينان معينى انجام مىشود. در مر موارد معمولى اين آستانه حدود هو درصد و يا بيشتر است. توجيه يراكندگى رگَبارهاى آذربايجان با صرف محاسبهى رابطهى همبستخى آمارى آن با ميزان رطوبت تودههاى هوا كافى نيست، بلكه بايد اين همبستخى از طريق يردازشهاى آمارى در حداقل اطمينان هو هو

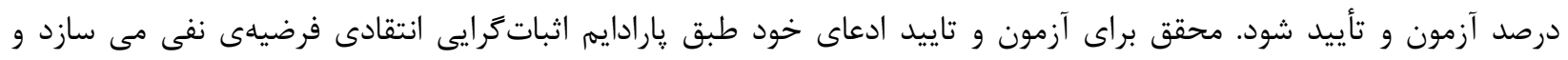

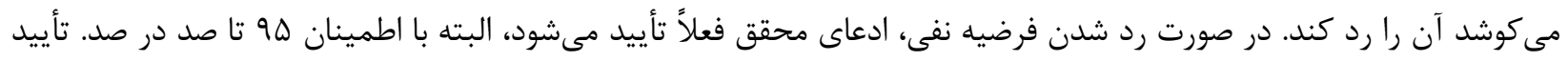
فرضياى تحقيق نظريهى جهانى را توسعه و گسترش مىدهد. در صورت رد شدن فرضيهى تحقيق بايد در جستوجوى اصلاح و يا

جايكزينى نظريهى جهانى بود. درونيابى: يكى از مهمترين اهداف تحليل فضايى استخراج داده براى نقاط بدون داده است. براى نمونه در همه جاى ايران ايستخاه هواشناسى وجود ندارد. اما كاربران مانند كشاورزان دوست دارند در همهى جاى ايران كشاورزى كنند و براى اين منظور به دادههاى هواشناسى نياز دارند. براى اين منظور بايد بر اساس دادهاى موجود اطراف براى نقطه مورد نظر داده تهيه كرد. اين فرايند به درونيابى موسوم است. روشهاى اوليه و سادهى اين كار ميانكين و يا مثلثبندى و غيره است، كه هيجكدام دقيق نيستند. از نظر متخصصان زمينآمار درونيابى بايد بر اساس ساختار يراكندگى يعنى هر دو رفتار منطقهاى و محلى انجام شود. اين 
روش درونيابى در كل كريجينَ (Krige, 1994) ناميده مىشود كه در شرايط فعلى دقت آن از ساير روشها بيشتر است. فرايند

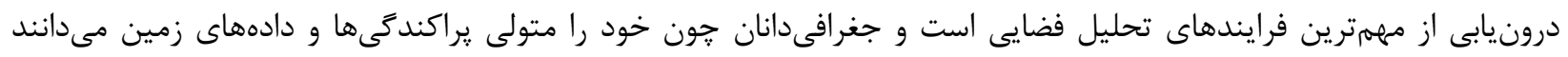

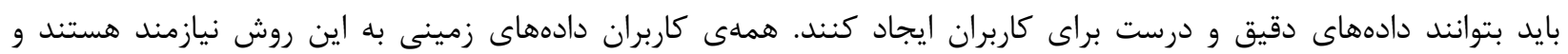

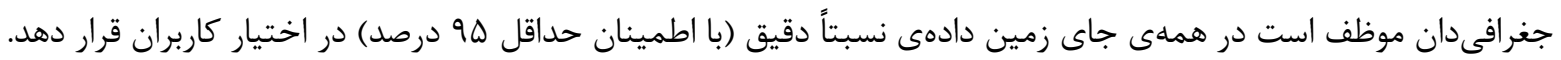
برنامهريزى فضايى: يس از توصيف و استدلال منطقى و درست يراكندگىها و استخراج داده براى نقاط بدون داده، نوبت به كاربرد اين دانش در سطح جامعه مىرسد. به عبارت ديگر، همهى مراحل توصيف و استدلال به منزلهى تبيين كامل تحليل فضايى به معرفت يا دانش علمى يراكندگى ها مىانجامد و زمينهى كاربرد اين دانش علمى را فراهم مى كند. اكنون جغرافىدان بايد بتواند

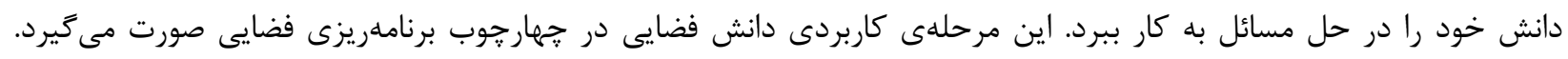
جغرافى دان مىتواند بر اساس دانش فضايى داشتهها و نداشتهها مناطق يرمخاطره را شناسايى كند و عوامل خطر را تشخيص دهد.

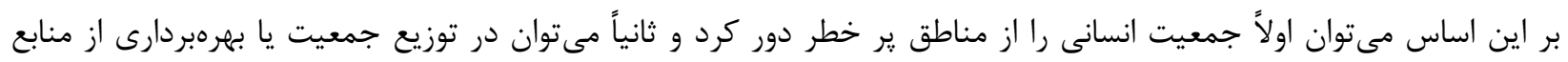
طبيعت برناملى منطقى و مطابق با شرايط محيط ارائه داد. برنامهريزى فضايى مههمترين و بنيادى ترين زيرساخت توسعه و تعالى هر

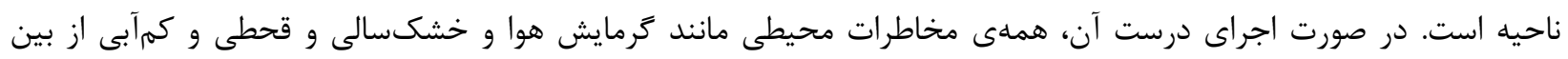
مىرود، زيرا همهى انسانها با توجه به توانمندىهاى محيط توزيع شده و فعاليت مى كنند. در هيججايى به محيط صدمه وارد نمىشود. همهجا زندگى در حال تعادل است، در اين صورت است كه شعارهاى كنفرانس ريو + •r عملى مىشود و جهان به

\section{نتيجه}

تحليل فضايى نكرش اصلى جغرافياست كه بعد از جنَ جهانى دوم در يى تمايل جغرافىدانان به استخراج و كشف نظريهها و قوانين جهانى به همراه جغرافياى كمى ايجاد شد. ابتدا در جغرافياى انسانى استفاده كرديد و سيس به جغراسئ جغرافياى طبيعى هم گسترش يافت. هدف تحليل فضايى توصيف و استدلال يراكندگى ها به منظور توليد و آزمون نظريههاى براكندگى هاست. از ديدگاه فلسفهى علم، هستىشناسى اصلى آن هستىشناسى مستقل و معرفتشناسى آن عينى است، زيرا ويزگى هاى يراكندگى ها جه دربارهى متغيرهاى انسانى و جه دربارهى متغيرهاى طبيعى مستقل است و هيج ارتباطى به تفكر انسان ندارد. دانش نهايى آن آن دانش علمى است كه مطابق با طبيعت و از طريق روش منطقى حاصل مىشود و عينى و مستقل است. به عبارت ديكر، انسان اين ويزگى ها يا نظريههاى يراكندگىها را نمىسازد، بلكه آنها را كشف مى كند. در اين باره، انسان فقط مفاهيم مربوط به حيطهى انسانى را مانند آسايش آب و هوايى و مديريت مناسب شهرى تعريف مى كند. روشىشناسى اصلى تحليل فضايى روش شناسى كمى است، زيرا بدون استفاده از روشهاى كمى و زبان رياضى نمىتوان دادهاى فراوان را خلاصه كرد و به دانش علمى و قابل استفاده

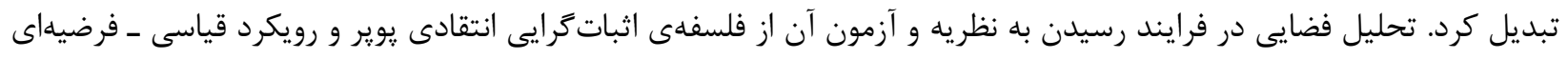
يعنى همان روش علمى استفاده مى كند. در بیى ايجاد سيستم اطلاعات جغرافيايى در دهلى • •191 تحول و بسط تحليل فضايى جند برابر شد و سيستم اطلاعات جغرافيايى محيط عملياتى و اجرايى تحليل فضايى را فراهم آورد. اگرجه جغرافياى انسانى در دهdهاى • لو ا به دليل كمى بودن از اين نكرش فاصله گرفت، اكنون همهى رشتههاى جغرافيا به نوعى با اين ديدگاه بلهويزه در

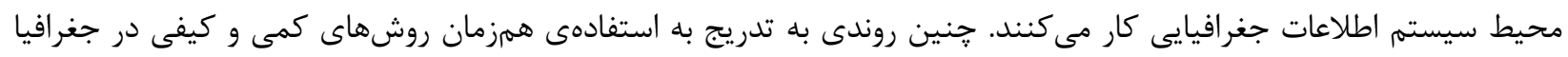




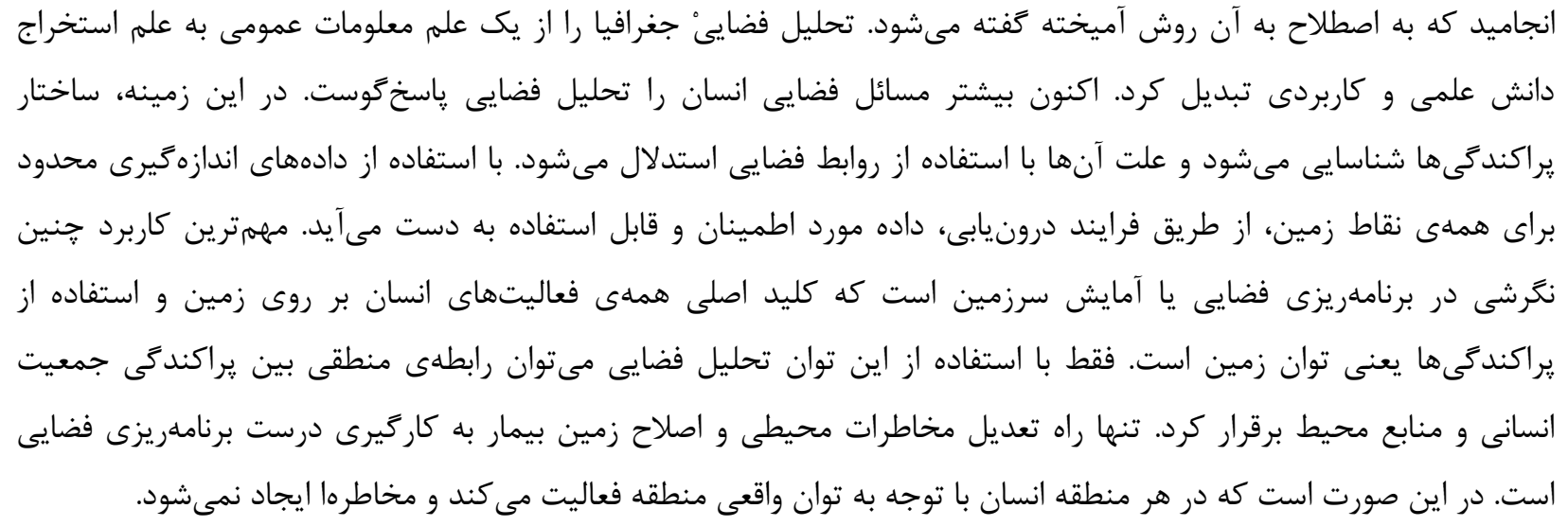

Abler, R. F., Adams, J. S. and Gould, P. R. 19v1: Spatial organization: the geographer's view of the world. Englewood Cliffs, NJ: Prentice-Hall.

Anselin, L. १९१९. Exploratory spatial data analysis and Geographic information systems. Research paper qr५q. Regional Research Institute, West Virginia University, Morgantown, USA.

Anselin, L., Florax, R. J. G. M. and Rey, S. J., (eds). r.. F. Advances in spatial econometrics: methodology, tools and applications. Berlin: Springer.

Barnes, T.J. r. II. Spatial Analysis. In: Agnew, J.A. and D. N. Livingstone (eds.). r. 11. The SAGE Hand book of geographic knowledge. SAGE Publications, London.

Beck, R. Iq९V. Spatial meaning and the properties of the environment. In Environmental Perception and Behavior.

Research Paper No. 1.9, ed. D. Lowenthal, 1^-५9. Chicago: Department of Geography, University of Chicago.

Berry, B.J.L. and D. F. Marble, (Eds.). । १९৯. Spatial Analysis: A reader in geography. Prentice- Hall Incorporations,

Englewood Cliffs, New Jersey.

Bunge, W., 1974. Theoretical Geography. Second Edition. Lund Studies in Geography.

Series C: General and Mathematical Geography, No. '. Lund, Sweden: Gleerup.

Chorley, R.J. and P. Haggett, (eds). 19९v. Models in Geography. London: Methuen.

Curry, M.R.Y.・ . Toward a geography of a world without maps: Lessons from Ptolemy and postal codes. Annals of the Association of American Geographers, $9 \Delta: 9 \wedge \cdot-991$.

Fotheringham,A.S., C. Brunsdon, and M. Charlton. r... Quantitative geography: Perspectives on data analysis. Sage publications, London.

Fotheringham, A.S., C. Brunsdon, and M. Charlton, r..ץ. Geographically Weighted Regression. Hoboken, NJ: Wiley.

Gethis, A. $\uparrow \cdot \wedge$. A History of the Concept of Spatial Autocorrelation: A Geographer's Perspective. Geographical Analysis, $\boldsymbol{\varphi} \cdot:$ : १५-r.१.

Golledge, R. G. r..r. The Nature of Geographic Knowledge. Annals of the Association of American Geographers, qr(1): $1-14$.

Goodchild, M. F., and L. Anselin. Y... Spatially integrated social science: Building the research infrastructure. Paper presented in honor of Reginald Golledge at the Association of American Geographers, Pittsburgh, PA. 
Goodchild, M.F. 1941. A spatial geographical perspective on GIS. International Journal of Geographical Information System, I: rrv-rrm.

Goodchild, M.F. and D.G. Janelle, r..r. Thinking spatially in the social sciences. In

M.F. Goodchild and D.G. Janelle, editors, Spatially Integrated Social Science. New

York: Oxford University Press, pp. r-rץ. Gregory, S. 19६ץ. Statistical methods and the geographer. London: Longman.

Haggett, P. ( $\ldots$. I): Geography: A Global Synthesis. Prentice Hall, Harlow, ^r p pp.

Haggett, P. $199 \Delta$. Locational analysis in human geography. London: Edward Arnold.

Haggett, P. 199•: The geographer's art. Oxford: Balckwell.

Hartshorne, R. 19r9. The Nature of Geography: A Critical Survey of Current Thought in the Light of the Past. Association of American Geographers, Lancaster, PN. USA.

Harvey, D. 1979 . Explanation in Geography. Arnold, London.

Johnston, R. ץ.^. Sixty Years of Change in Human Geography. In: Proceedings of the History of Postwar Social Science Seminars, London School of Economics, ro April r.. . , edited by Backhouse and Fontaine.

Johnston, R. J. 199ধ. Spatial Analysis. in R.J. Johnston, D. Gregory and D. M. Smith (eds), The Dictionary of Human Geography. Blackwell, Oxford.

King, L.J., 1999. Statistical Analysis in Geography. Englewood Cliffs, NJ: Prentice-Hall.

Krige, D.G. 1999 . Two dimensional weighted moving average trend surfaces for ore-evaluation. Journal of the South

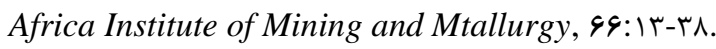

Law, J. Y.. ץ: After method: mess in social science research. London: Routledge.

Mathews, J.A. and Herbert, D.T.(eds). ץ.. . Unifying geography: Common heritage, shared future. Routledge, London.

Miller, H.J. ץ •^^. Geographic theory and geospatial knowledge discovery. IEEE International Conference on Data Mining. Pisa, Italy - $\wedge$ December $\uparrow \cdot \wedge$.

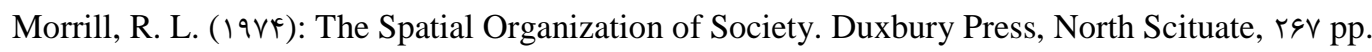

Morrill, R. L. 19४•: The spatial organization of society. Belmont CA: Wadworth.

National Science Foundation (NSF). $r \cdot 11$. Geography and spatial sciences (GSS) Program and strategic plan, $r \cdot 11-$

$r \cdot 10$

Pattison, W.D. 197 r. The Four Traditions of Geography. Journal of Geography, 7 r. Y 11 - r 17.

Schaefer, F.K. 19०r. Exceptionalism in geography: A methodological examination. Annals of the Association of American Geographers, $\leqslant r(r):$ r r $r-r \leq q$.

Richardson, D. r.... Bringing Geography Back to Harvard. AAG Newsletter of the Association of American Geographers. December $r \cdot \cdots \Delta$.

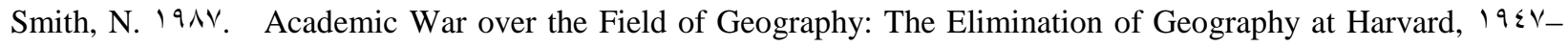
1901. Annals of the Association of American Geographers, $\vee V_{0}$ 100_ $1 \mathrm{VY}$.

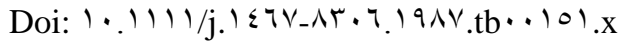

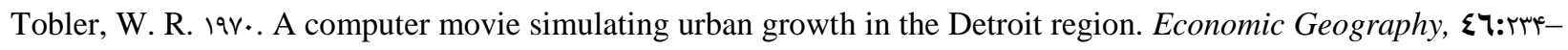
r.

Wilson, A.G. and R.J. Bennet. 19^৯. Mathematical methods in human geography and planning. Wiley, London. 